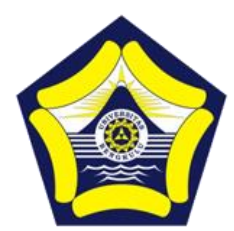

\title{
Phenomenologizing the Leadership Practices of the Selected School Heads in the Philippines
}

\author{
Norma Cordero Najera", Amelita A. Gearlan \\ University of Santo Thomas, Graduate School, Manila, Philippines \\ *Email: noimecor@gmail.com \\ DOI: https://doi.org/10.33369/jeml.2.1.1-9
}

\begin{abstract}
Educational leadership has been one of the interesting arguments of many academic researchers over the years. School heads have significant tasks to fulfill as they are responsible for the entire operation of the school as instructional and organizational leaders. In Catholic institutions, school heads are also accountable for the integral formation of the students, as well as the spiritual well-being of faculty and staff, parents and the stakeholder. Most often, they are challenged by various obligations and they need to have strong spirituality in their leadership practices. This qualitative study attempted to describe the leadership practices of a select group of heads of schools run by the Franciscan Sisters of the Sacred Hearts in the Philippines as basis for a proposed leadership formation framework. Thirty (30) heads of schools participated in the study. Among them, six (6) were Principals, six (6) were assistant principals, twelve (12) were academic coordinators and six (6) were heads of different offices. They underwent semi-structured depth interviews. The findings formed "The Whirl of Christ-Centred Leadership Model for Heads of Schools"describes the common practices and the critical instances which make the onset experience, and the value engagements that are observed in the institutions. The findings of this study provides valuable inputs to help school heads to become more inclined and spiritually empowered to influence people, work collaboratively that may result to a progressive and smooth working environment.
\end{abstract}

Keywords: Leadership, Practices, Spirituality, School Heads.

\section{INTRODUCTION}

Leadership is commonly used as the responsibility given to the person who is in-charge of the overall operation of the school such as the administrators, principals, dean or president. They are called leaders since they influence teachers in doing their responsibilities as teachers: how they manage the classrooms, handle the learners, relate with parents as well as how to deal with their colleagues.

According to Sander (2013), leadership is the capacity of a person to influence other people to make a difference, to effect change and attain the institution's plan. The degree of influence will depend on the personality, the incandescence of which one is capable, and the flame which burns within, the magnetism which will draw the hearts of others toward him/her. This is because true leaders are called to accomplish missions in life. Leaders are people with great conviction that what they sow is for the good of all those under them.

In Catholic school, leadership takes another implication. It is leading through examples, witnessing and exercising the faith (Buck \& Bradbury, 2014). This is the reason why a principal in a Catholic school takes double tasks. Principals need to undergo certain preparation before taking the responsibility (Neidhart $\&$ Lamb, 2016). On the other hand, Belmonte (2009) suggests that in order to maintain Catholic school identity, principals as leaders of schools "need to be not only be professionally competent but spiritually competent as well" (p.308).

Gibson, (2011) reviewed eight studied on spirituality in educational leadership and find out that their spirituality has significance in educational leadership and effectiveness within the institution. According to him, spirituality enkindles educational leaders to contribute to such things as building mutual understanding, pliability and effectiveness within the institution. The spiritual values and practices related to leadership effectiveness provides a foundation for developing a leadership theory that assimilates character and behavior, motivation and performance, in a cross-cultural model. For Reave (2005), examining the 
relationship between spirituality and leadership provides deeper understanding of the leaders' motivation in their performance that determines spiritual values such as integrity, honesty and humility.

Spirituality comes from the word "spirit", "ruach" in Hebrew or "pneuma" in Greek which means "wind or breath" (Sheldrake, 2016). Christians define spirituality as "life in the spirit of God" or living according to the will of God" (Guinan, 1988). For Catholic tradition, spirituality traced back to the letters of Paul in which he uses the Greek term "pneuma" to signal a life lived in alignment with God's Spirit. Christian spirituality presumes, through God's grace, a human desire and capacity for growing in union with the Triune God (Griffith, 2009). This signifies that to live conscious relationship with God in Christ through the Spirit, and to adhere a life of deep conversion in order to attain the goal of discipleship, to live a life of piety, service, and to cultivate values and virtues.

Literature does not have a common definition of spirituality. Different authors has their own personal understanding in connection to their personal experience. Smith's (1999) definition of spirituality is the dimension of life, complementing the psychological and physical aspect, which gives meaning to one's life and calls the person towards the higher self. It is usually expressed as some form of relationship with divine being, which in the Christian tradition is called God. Spirituality refers to the higher intensity of aliveness rather than just about keeping rules but it is about delighting in the wonders and the fullness of life.

In the field of education, several authors have given different meanings of spirituality. In his article spirituality in educational leadership, Gibson (2011) defines spirituality as socio-cultural and transcendent connectedness, making meaning about life and living, and a desire for greater authenticity, resulting in inconsistency between people's belief, moral-values, attitude and their actions. Though Gibson does not connect spirituality to the Divine being, the idea of connectedness and giving meaning to life is still present in understanding what spirituality is. Ramírez (2009) defined spirituality as a human being's unique relationship to that which is perceived by the individual, to be divine, beyond the bodily senses, time and the material world. This is a phenomenon that educators should not neglect since educators need to cope with different challenges they encounter in their works.

The Congregation of the Franciscan Sisters of the Sacred Hearts (SFSC) is founded in 1886 in Rome Italy by an OFM-Alcantarine friars named Fr. Simpliciano of the Nativity, OFM. It constitutes two Provinces of Italy and the Philippines. Apart from two provinces, SFSC has also two Delegations in Indonesia and India. In the Philippines, the total population of SFSC is 187 in 2020. The main apostolates of the Congregation are education, caring for the abandoned and wayward children, hospitality and pastoral works. There are six schools run by SFSC in the Philippines. The Immaculate Heart of Mary College, Paranaque City, Immaculate Heart of Mary School, Bulacan, Immaculate Heart of Mary School, Bulusan, Immaculate Heart of Mary School, Bacon, Fr. Simpliciano Academy, Paranaque City and Mater Divinae Gratiae College, Dolores, Eastern Samar. School heads of these schools are religious sisters and lay people.

As heads of Catholic schools, Principals, assistant principals, academic coordinators and heads of different offices in all SFSC managed schools are selected carefully. Formerly, it is a common understanding that qualified candidates to be school heads are those who obtain Masters or Doctoral Degree. But this is not solely the assurance to become a good leader. They need to integrate spirituality in their leadership practices because educational leaders with their demanding and consuming jobs, are included in the ranks of those leaders most requiring a replenishment of the spirit (Houston, 2002). They need to find connection between their work and their inner being (Ramirez, 2013).

The challenge among SFSC heads of schools lie not so much on their skills but on how they integrate spirituality in their leadership practices. Their personal lifestyle, decisions and actions, should manifest the traits of a spiritual leader who have faith in God, humble, loving and caring, compassionate, just, empowering, collaborative and service oriented (PCSS 2016).Hence, in Catholic Schools the responsibility of school heads is not solely confined in the attainment of academic performances of students and good classroom management of teachers but also in the accomplishment of the spiritual activities and spiritual formation of students as well as of all its employees.

According to Back \& Bradbury (2014), school heads are leaders of faith nourished by the sacraments they have received and of the values that stream from who they are as Catholic Christians. They are also models of moral conduct among teachers and other employees(Doctrine of Catholic Faith, 1988) From this point of view, leadership should not be separated from who they are, but rather they should manifest spirituality in their practices, the one whose model is Jesus Christ, the great teacher (PCSS, 2016).

Unlike many studies that focus on the relationship of spirituality in the leadership practices of public school principals (Dixon, 2002; Ramirez, 2009; Wellman, 2009, Riaz, 2012; Werts, 2012), the 
purpose of this inquiry is to examine spirituality in the leadership practices of heads of schools run by the Congregation of the Franciscan Sisters of the Sacred Hearts (SFSC) in the Philippines. It would be interesting to conduct a study on the spirituality in the leadership practices of school heads to prove that to be a good leader is not a guarantee just to have managerial and instructional skills but also should manifest spirituality in their leadership practices. Likewise, there is a need to prove that spirituality has contributing elements in preserving Catholic school culture and in developing positive relationship among leaders and employees when they manifest faith in God, altruistic love, humility, compassion and justice in their praxis (Dayler \& Fry, 2012; Earl, 2013; Neidhart, H. and Lamb, J.T., 2016, Spesia, 2016). Moreover, conducting research in this area would contribute to the existing knowledge and literature on the area of spirituality in leadership practices for as of this date nobody has investigated yet on spirituality in the leadership practices among heads of schools run by SFSC in the Philippines where this study was conducted.

\section{RESEARCH METHODS}

This phenomenological study explored and described the spirituality and leadership practices of the school heads (principals, assistant principals, academic coordinators and heads of different offices) in the Schools run by Franciscan Sisters in the Philippines. The research appraoch adopted for the study was qualitative follwing the descriptive phenomenological design to understand the essence, or essences, of a class of phenomena experienced and shared by a group of persons (Creswell, 2009; Wojnar and Swanson, 2007).

A letter of request for permission to conduct the study and a letter of consent to be signed were sent to the heads of schools run by SFSC. Hence, from 42 identified qualified school heads, only 30 gave their consent. Upon receiving their consent from the participants, rapport was built to establish confidence and familiarity. There was an assurance letter that their name will be preserved with utmost secrecy following the code of ethics for research. Participation was voluntary and could be withdrawn at any point of time if the participants decided so. There was no monetary recompense included but this study benefited not only the researcher but the participants as well since it offered the opportunity to deeply reflect about their spirituality in their leadership practices. As countenance of their free disposition to participate in the study, the participants were asked to sign the consent form. The interview was done using audio-recording devise with the consent of the selections and was transcribed later by the researchers with outmost care.

\section{RESULTS AND DISCUSSION}

From a thorough and warm analyses of respondents' verbalizations, the Whirl of Christ-Centered Leadership Model (WCCLM) (see Figure 1) emerged. Stimulatingly, the Whirl of Christ-Centered Leadership Model describes various practices experienced by the school heads in their respective institutions. As shown in figure 1, the core part of the whirl of Christ-Centered Leadership Model describes the indispensable spirituality of a good leader, namely: Faith in God in Decision-Making; Humility in Greatness; Justice and Compassion in Leading and Love in Service.

\section{Faith in God in Decision-Making}

The problems encountered by the school heads relate to problem-solving and decision-making which requires thorough investigation and just or reasonable solution. Faith in God is identified in this study, for having faith in the God will help school heads make appropriate and humane solution to a conflict. In many of these duties and responsibilities, the school heads expressed their issues and concerns regarding the impact of faith on their decision-making.

Faith in God in decision-making is one of the components of spirituality that was identified in this study. Faith is the assurance of things hoped for, the conviction of things not seen (The Catechism of Catholic Church 1990). Faith is the capacity of human beings to believe in something they can't rationally prove. Therefore, faith is not a compartmentalized dimension of life but it is the driving force of one's being and perseverance.

To continue their tasks as leaders, heads of schools are to be founded in strong faith in God so as to be able to form a community of believers according to the vision of the Church (Earl, 2005). Drahmann and Stanger (1989) divide this role into two parts: the spiritual attributes that a person brings to the job through a personal faith experience, and the pastoral competencies to create a prayer environment, develop a sense of community service, witness to the faith and integrate the Gospel message into the curriculum. 
It is clearly manifested in the leadership practices of heads of school run by SFSC. As leaders of Catholic institution it is significant that leaders manifest their faith in God as Buck and Bradbury (2014) said that, being a leader, one cannot just leave faith or your belief outside the door of the school. A Catholic school is a faith community and the Catholic faith should be practiced and shared. Leadership spirituality for heads of school run by SFSC does not eliminate their faith in God. One participant articulated thus: "For me my faith makes me strong in the challenges I encountered in my leadership. The time that I don't know what decision I should make, I ask God the guidance to know which is better for the institution and for the people under my care."

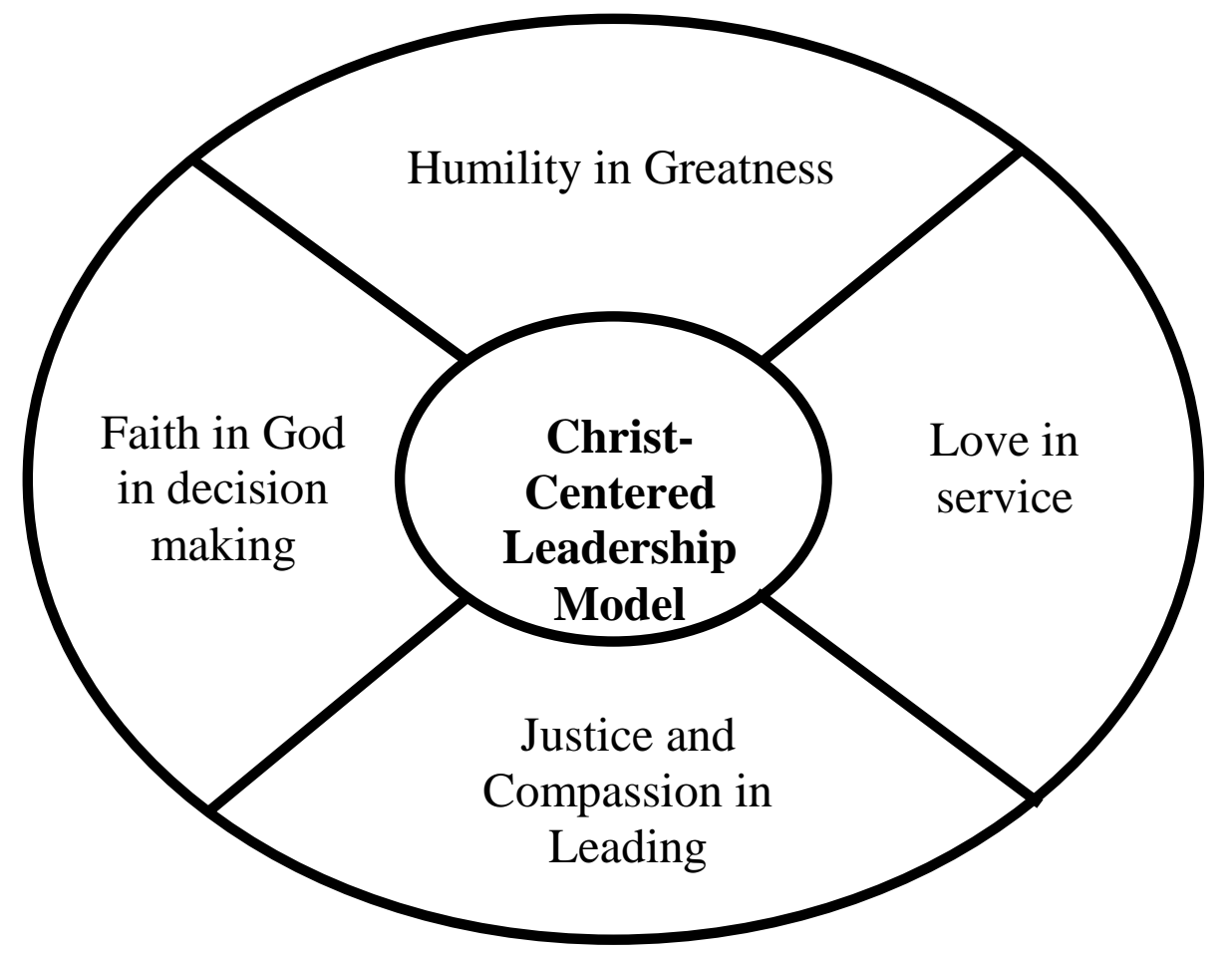

Figure 1. The Whirl of Christ-Centered Leadership Model

The leadership spirituality of school leaders is very substantial since they are the advocates in shaping the institution's beliefs and values. The findings of Niedhart \& Lamb, 2016 attestedthatprincipalsarestandingforwhattheybelieveandwhattheyhavelearned from Catholic Church and therefore they are encouraging children, faculty and parents of the school to build a community of faith. They are called to be missionary in the school where they work.

On the other hand, school heads as leaders must foster the spiritual and faith formation of all the stakeholders; students, teachers, parents and the community. Faith that is alive and not dead for by their fruits you will know them. For this purpose, it is significant that they themselves manifest faith spirituality in their leadership practices. They are to be distinguished as leaders with strong faith and not solely characterized as private school leaders with academic excellence.

\section{Humility in Greatness}

Humility in greatness was identified in this study. There are various situations wherein humility is tested. In dealing with individual differences or diverse culture, most of the time it needs huge understanding and acceptance, even sometimes one is in unfortunate circumstances, being deprived and degraded by people, but still to be gentle and humble in dealing with the situation is a good attitude in order to live in a harmonious and peaceful working environment.

Humility is a spirituality that most leaders need, but most likely leaders fail to realize in their practices. It is natural for individuals to be proud of themselves when they are promoted. It is an instinct that a 
human person has. On the contrary, as regards to the spirituality of Jesus' leadership, he emphasized the importance of being humble in dealing with other people. From His stand point, the one who leads is not the one who is served but the one who serves.

In the Filipino culture the spirit of humility in leadership is also hard to practice since it is already a culture rooted among the Filipinos to take pride of whatever position one has in the workplace. Reave (2005), believes that leaders who are humble appear to be effective leaders because of their capacity to admit feedback. The opposite of humility is having a high regard and a high opinion of oneself, not open to receive negative feedback. Persons who are proud may also show aggression to others, disturb others and infuriate others more often.

Humility being an important part of spirituality is a value that stresses not having pride over other people (Selver, 2013). In this point of view, living in the spirit of humility, school heads can exercise their leadership without putting themselves on the pedestal that their actions and decisions are to be always followed instead they should also solicit opinions and suggestions from the members of the educative community. "As head of elementary department, I bear in mind that even being a leader, I am not always right. For that reason I also solicit opinions from the teachers and ask them what are the necessary things to be done especially with regards to the different programs we need to implement in our department".

Humility is the key for effective leadership (Gonzalvo, 2017). The examples of St. Francis of Assisi and Mother Theresa of Calcutta who responded to the call of God with genuine humility. Assures that, God would be glorified and not them. For this reason, many people were attracted to join their institution. School heads first and foremost are ecclesial ministers and they are servant leaders within the wider Church Community (Spesia, 2016). As leaders, they should strive to maintain the spirit of humility and to carry on the spirit of service to others as they are living witnesses to the faith and mission of the Church. They are to realize in their leadership Jesus' leadership style which is clearly manifested when he said I came to serve and not to be served.

\section{Justice and Compassion in Leading}

The third identified indicator in the whirl of Christ-Centered Leadership Model is Justice and Compassion in leading. The school heads shall be just and compassionate in giving judgment in establishing good relationship among school constituents. These qualities could possibly impact teachers and students' performances as well as development within the educational system.

Justice is the moral virtue that consists in the constant and firm will to give their due to God and neighbor. Justice towards God is called the "virtue of religion." Justice towards men disposes one to respect the rights of each and to establish in human relationships the harmony that promotes equity with regards to persons and to the common good (Catechism of Catholic Church, 1995).Justice is identified in this study as one of the spiritualities in the leadership practices since heads of schools as leaders are called to be the role model of teachers and students in observing fair treatment to everyone. It is known to most of us that favoritism and preferences cannot be avoided in schools. Sometimes problem arises because of the injustices in giving grades to learners by the teachers as well in giving performance rating to teachers by their respective principals.

The code of ethics for professional teachers highly recommends that under no circumstance shall teachers be prejudiced or discriminate against a learner (sec.3). Moreover, a teacher shall base the evaluation of the learner's work only in merit and quality of academic performance (sec.6).as one respondent said; "I always encourage our teachers to have a fair treatment to each student whether they are performing or not performing well in the class. Knowing that we are here committed to achieve vision, mission goals and objectives of the school. I am actually looking forward that our graduates will become successful and competitive with the heart.

The word compassion came from the Latin word com (with) and pati (to suffer). It literally means "to suffer with." (Catholic Dictionary) In English language it originally means showing love and passion to others. In his book on ethics and spiritual development, Dalai Lama (1999) defines compassion as one of the principal things that make our lives meaningful. For him, it is undeniable that if society suffers, we ourselves suffer, yet, as long as we have compassion for others and conduct ourselves with restraint out of a sense of responsibility, there is no doubt we will be happy.

In the educational institution, compassion isn't just about being merciful to others rather it's a decision, an action to nurture others to their full potential. To practice compassion in leadership, one invest time into people to contribute to their growth and set them on a path for success. In going out of their way to 
reach others, leaders make their subordinates overcome their problems physical or emotional and help them to become open.

In the article written by Juneja (2017), she mentioned that compassionate leaders are effective leaders because they possess sensible hearts, know how to understand the feelings of others and would be very much responsive to their needs before their own.

Tan (2012) made mention that compassionate leaders are effective leaders since the leaders with compassion go through an important transformation, that is going from "I" to "we". Specifically, he defines compassion as having three components: 1) A cognitive component: "I understand you", 2) An affective component: "I feel for you", 3) A motivational component: "I want to help you. In this study compassion is consider as one of the construct of spirituality to know if heads of schools, being leaders of an institution does not only implement rules and regulations yet they should also manifest compassion in their leadership praxis.

In the study made by Gabruch (2014), he attested that to be compassionate leader, one needs selfreflection and personal transformation. Compassionate leaders are those who has good communication with others, engage in positive emotions to encourage, implement rules and regulations for the greater good, put other's needs before their own, are aware of their own performance, speak candidly but listen with the heart and approachable. When there is misunderstanding between employees, they encourage forgiveness and offer learning from their mistakes so as to build positive relationship based on reverence and appreciation. Information is shared to promote collaboration and belongingness in the institution. As one respondent in this study answered that, Before I make important decisions, I see to it that it is always in accordance in the school manual. If there is still something that we can do, I am trying my best to practice a-win-win decision.

Compassion is indispensable for effective leadership practices (Berchowicz and Myers, 2014). Educational leaders who use compassion as a foundation of their leadership focus on listening so that they can learn to understand what actions they must take to resolve issues; it is accurately and symbolically the head working with the heart. Compassionate leadership makes available a source of strength for the intellectual development and social-emotional learning of students and teachers. In times of conflict everyone must show calmness and fairness, so that relationship will become harmonious in the working environment and each member will also become compassionate in attending their respective duties and responsibilities.

\section{Love in Service}

In this study, the love in service is identified. It can be deduced that as heads of schools they demonstrate love in serving people. It is important to express the love through genuine service to others.

Love in Service or love of others is the spirituality taken from the command of Jesus to love others as you love yourself (John 15: 12-13). In spiritual leadership promulgated by Fry (2003), he defines altruistic love as a sense of wholeness, harmony, and well-being produced through care, concern and appreciation for both self and others. He emphasizes the importance of the character of a leader who realizes the vision of the organization; the sense of belonging between leaders and followers as expressed in their genuine concern and love for each other. Results of practicing altruistic love in an organization produce strong dedication and effectiveness and the fruits of these are joy, peace and contentment. "As I help others to improve in their performance, I am also happy because I can share my knowledge and skills to them knowing that in the future they will also be a leader like me and I hope they will do the same to the their constituents."

In our world today where competitiveness is common among workers, altruistic love is not in the vocabulary of many. The mindset is to work well for oneself, for promotion and to increase salary. For these, many do not mind others whether they too excel or are already left behind as what is important to them is to attain their personal goal. On the contrary, leaders living with spirituality of altruistic love should encourage everybody to excel in their particular job for the good of the institution. Argandona (2011), argues that the mechanistic view of organizations focuses primarily on the procuring of resources, making of goods and services, and selling of goods and services leaves no room for love.

The effectiveness of altruistic love in an organization was studied in Nigeria by Ahiauzu \& Asawo (2010). Their quantitative study showed that one factor that highly motivated workers' commitment was because altruistic love was visible within the organization. They recommended that studies on altruistic love in the workplace be conducted to measure multiple outcomes. Altruistic love takes away fears associated with worry, anger, jealousy, selfishness, failure and guilt and gives one a sense of membership that part of spiritual survival that gives one an awareness of being understood and appreciated (Fry, 2003). 
The above findings proved that manifestations of altruistic love in the leadership practices of heads of schools help the institution to grow in their understanding with one another and leave room for the improvement of the performance of all employees particularly the teachers since the growth of everyone is the main purpose of the leaders.

\section{CONCLUSION}

This study was conducted to scrutinize spirituality in the leadership practices of selected heads of schools run by the Franciscan Sisters of the Sacred Hearts in the Philippines. Results of this study attested that spirituality in the leadership practices is highly significant in order to perform well as leader in the educational institution. In the challenges that heads of schools are encountering in their day-to-day obligations, it is important that at the end of the day they have practiced their spirituality that helps them to carry on their duties and responsibilities with total dedication. To be a leader is not an easy task. Hence, if one practices the spirituality of faith in God, altruistic love, is humility, compassion and justice, their undertakings will have meanings in their life likewise in the life of others. The Whirl of Christ-Centered Leadership Model emerged out of this study will help heads of schools to be more equipped in doing their day to day responsibilities as leaders of their respective institution so as to carry on their Vision and Mission. Likewise, this study implies that school leaders need not to have only managerial and instructional skills but likewise should integrate spirituality in their leadership practices in order to vitalize the spirituality of good leaders in the image of Jesus Christ who is loving, humble, compassionate and just.

\section{REFERENCES}

Argandona, A. (2015). A framework for the analysis of spirituality at work. IESE Business SchoolUniversity of Navara.

Asawo, SP \& Ahiauzu, A. (2009). Unwavering hope and workers'committment in the Nigerian manufacture industry: a study in workplace spirituality. Research Gate.

Belmonte, A. (2009). The religious dimension of lay leadership in Catholic schools: Preserving Catholic Culture in an Era of Change. Catholic Education: A Journal of Inquiry and Practice, 12( 3), 294-319.

Berkowicz J. \& Myers A. (2014). Leadership, learning and compassion. The Indispensables of Education. https://www.lollydeskal.com

Black, G. (2010). Correlational analysis of servant leadership and school climate. Catholic Education: A Journal of Inquiry and Practice, 13(4), 437-466.

Buck, M. \&Bradburry, G. (2014). Leadership and spirituality-ethos and Vocation. Catholic Education Service.

Clarken, R. (2009). The Role of spirituality and spiritual practices in education, of Education. Dissertation Paper presented at the American Educational Research Association Annual Meeting, Northern Michigan University, San Diego.

Congregation for Catholic Education. (1988). The religious dimension of Education in a Catholic school: Guidelines for reflection and renewal. Washington DC: United States Catholic Conference.

Cook, T, \&Durow P. (2008)The upper room: A university archdiocesan partnership to develop leaders for Catholic schools. Catholic Education: A Journal of Inquiry and Practice, 11( 3), 355-369.

Drahmann T., \& Strenger, A. (1989). The Catholic school principal: An outline for action. Washington, DC: National Catholic Educational Association.

Dixon, V. (2002) Spirituality and academic performance among African-American College students. Research Gate.

Duchon D \& Petchsawanfa P. (2009). Measuring workplace spirituality in an Asian context. Unversity of Nebraska-Lincoln.

Earl, P. H. (2013). Spiritual formation for Catholic educators: Understanding the need. Journal of Catholic Education, 8 (4).

Fry. W.L. (2003). Toward the theory of spiritual leadership. The Leadership Quarterly, 14(6), 693-727.

Gabruch D. (2014). Compassionate leadership: A model for organizational well being in the 
workplace. Athabasca University, Athabasca, Alberta.

Geaney, M. (2012).A spirituality leadership competency model: What does it take to be a spiritual leader in business? Retrieved from; https://www.stthomas.edu/media/catholicstudies

Geigle, D. (2012). Workplace spirituality empirical research: A literature Review. Business and Management Review, 2(10), 14-27.

Gibson, A. (2011). Spirituality in educational leadership.TEACH, 5(1), 35-42.

Gonzalvo BJ, (2017). Catholic voices learninghumble leadership from the saints. Catholic Voices, Northwest Catholic

Greenleaf, R.K. (1977). Servant leadership: A journey into the nature of Legitimate power of greatness. New York: Paulist Press.

Greevy, A. \& Copley S. (1998). Spirituality and education nurturing connections in schools and classrooms Michigan State University. Retrieved from http://csf.colorado.edu/ HyperNews/get/sine/relationship.html

Groom, T. (1998). Educating for life: A spiritual vision for every teacher and parent. Allen, TX: Thomas More.

Guinan, M.D. (1998). Christian spirituality: Many styles, one spirit. Catholic Update, C0598.

Houston, P.D. Blankstein, S.L.\& Cole, R.W.(2008). Spirituality in educational leadership. Thousand Oaks, CA: Corwin Press.

John Paul II. (1979). On catechesis in our time. Boston: Daughters of St. Paul.

John Paul, II. (1981) Laborem Exercens, The Catholic Social Teachings, Vatican City. http://www.vatican.va/edocs.ENG217/

Jones, L. (2005) What does spirituality in educationmean?. Journal of College and Character, 6(7), Retrieved from http://dx.doi.org/10.2202/1940-1639.1485. Feb. 15, 2017

Jones, A. (2010), Leadership and spirituality: The indivisible leadership of African American school administrators as pastors. Doctoral Dissertation submitted to Iowa State University, Iowa.

Juneya P. (2015) Importance of compassion in leadership. Management Team Guide Content. Retrieved from https//management/study/guide/com

Karakas, F, (2010). Spirituality and performance in organizations: A literature Review. Journal of Business Ethics, 94(1), 89-106.

Kaya, A. (2015). The relationship between spiritual leadership and Organizational citizenship behaviors: A research on school principals' behaviors. Educational Sciences: Theory and Practice, 15(3). 597-606.

de Klerk, J. (2005) Spirituality, meaning in life and work illness: A Research agenda. International Journal of Organizational Analysis, 13(1), pp.64-68, doi: 10.1108/eb028998

Kouzes, J.M \& Posner, B. (2003).The leadership practices inventory-self. $3^{\text {rd }}$ ed. Hoboken, NJ: John Wiley and Sons. Inc.

Lama, D. (1999). Ethics for the new millennium. New York: Riverhead Books.

Laub, J.A. (1999) Assessing the servant organization development of the servant Organizational leadership assessment (SOLA) instrument. Doctoral Dissertation submitted to Florida Atlantic University, Florida.

Millard, B. (1995). Servant-leadership--it's right and it works!Colorado Springs: Life Discovery Publications.

Miller, R. (2006). Reflecting on spirituality in education. Encounter, 19(2), 1-5.

Musick, K. (2010). Spirituality and school leadership. A Doctoral dissertation submitted to the University of Denver.

Neidhart, H. \& Lamb, J. T. (2016). Australian Catholic schools today: School Identity and leadership formation. Journal of Catholic Education,

Newman, L. (2004) Faith, spirituality, and religion: A model for understanding the differences. Spring, 23(2). 102-110.

Philippines Catholic Schools Standard for Basic Education. PCSS (2016). Phoenix Publishing House Inc., Quezon City.

Ramirez, L. (2009) Spirituality in the praxis of educational leadership: Four Public school principals' perspectives on leading through spirituality. Doctoral Dissertation submitted to Texas Tech University, Texas.

Rayburn, C. \& Richmond, L. (1996). Inventory on spirituality. Unpublished Inventory.

Reave, L. (2005). Spiritual values and practices related to leadership Effectiveness. The Leadership 
Quarterly 16, 655-687.

Riaz, O. (2012). Spirituality and transformational leadership in education. FIU Electronic Theses and Dissertations Paper 654, retrieved from http://digitalcommons.fiu.edu.ed/654.

Salameh, K. (2011). Servant leadership practices among school principals in Educational directorates. International Journal of Business and Social Science V, 2 ( 22), 138-145.

Sander, S.O. (2013). Spiritual leadership. OMF Literature Inc. Manila.

Selver, P. (2013). Spiritual Values in leadership and the effects on organizational performance: A literature review. British University in Northern Columbia.

Sheldrake, P. (2016) Spirituality: A guide for the perflexed. London: T\&T Clark.

Spesia, D. D. (2016). Forming Catholic school principals as leaders of the new Evangelization. Journal of Catholic Education, 20(1), 244-265.

Tan, CM, (2012) Compassionate leaders are effective leaders. Harper Collins Publishers.

The Catholic School on the Threshold of the Third Millennium, Congregation for Catholic Education, Vatican City, 1998.

The Holy Bible, (1995) Standard English Version, Catholic edition.

Thom, D., \& Ma, Q., (2005) Educational leadership in the spiritual way, "Whatever will be, will be". New Horizons in Education, 52, 117-123.

Thompson, S. (2012). Hidden Strength: Encouraging spiritual leadership Attributes among school leaders.Kentucky Journal of Excellence in College Training and Learning10(9), 107-118.

Wellman, W., Perkins G., \& Wellman, N. (2009). Educational leadership: The Relationship between spirituality and leadership practices.Academic Leadership: The Online Journal, 7(1), 1-5.

Werts, A. Lindle, J. Clark, K. , Robert C.; Green, E. \&Salla, M. D. (2012). Knowledge, leadership and the role of spirituality: An exploration of principal as spiritual leader. Publications Paper. Retrieved on Feb. 2, 2017 from http://tigerprints.clemson.edu/eugene_pubs/9.

Wheatley, M.J. (2002). Spirituality in turbulent times. https: //www.aasa.org/ School Administrator Article.

Woods, G. (2007). The bigger feeling: The importance of spiritual experience in educational leadership.Educational Management Administrational Leadership, 35(1), 135-155.

Zohar, D. \& Marshall, I. (2004). Spiritual capital. CA: BerrettoKoehler Publishers Inc. 